\title{
IMPROVING STUDENTS' INTEREST BY USING PICTURE MEDIA AT TK NUR ASSALAM
}

\author{
Nada Anis Ristyani ${ }^{1}$, Nurhayati ${ }^{2}$, Hendra Husnussalam ${ }^{3}$ \\ ${ }^{1}$ IKIP Siliwangi \\ ${ }^{2}$ IKIP Siliwangi \\ ${ }^{3}$ IKIP Siliwangi \\ ${ }^{1}$ nadaristyani12@gmail.com, ${ }^{2}$ nurhayati_31@gmail.com, ${ }^{3}$ husnussalam@ @stkipsiliwangi.ac.id
}

\begin{abstract}
The purpose of this study is to improve students' interest in English vocabulary through picture media in TK Nur Assalam. This research is a Classroom Action Research (CAR). The participants of this research were 6 students. The results obtained from efforts to the improving students interest in English vocabulary using the picture media involving active learners in the learning process. The role of picture media in learning activities is very important for children, especially in the next education level. Teaching and learning activities in early childhood will quickly develop if parents and teachers intensive to develop it. There are several attempts to create a sense of pleasure in early childhood by using picture media in the learning process. From the result of research indicate that when pre-action take result $(15 \%)$. In cycle I, it increased to (55\%) sufficient criteria. In cycle II, it increased again to (85\%) good criteria. So, the increase that occurred from the pre-action to the cycle I that is $(40 \%)$. The increase from cycle I to cycle II that is (30\%). And increase from pre-action to cycle II that is $(70 \%)$. From the research results obtained, then to the improving students interest in English vocabulary can be improved by using picture media in the learning process.
\end{abstract}

Keywords: Students' Interest, Vocabulary, Picture Media

\section{INTRODUCTION}

English as an international language has an important role in everyday life every person around the world. English has an important role in education. All of people from various geographical, religious and cultural backgrounds have an agreed to communicate with each other is English. Currently in Indonesia learning English has started since in elementary school, junior high school even in some kindergartens (TK).

According to Mansur (2005) early childhood defined as a group of children who are in the process of growth and development that is unique. They have a special growth and development pattern according to their growth rate and development. Furthermore, according to Depdiknas (2005) early childhood is a child aged 0-6 years. At the age of 4-6 years it is important for children to get education because there are aspects within the 4-6 year old children that must be developed are the language, cognitive, social emotional, religious and moral values and physical motor.

The language aspect is one of the most important aspects of development for children. The purpose of this language aspect is to increase the vocabulary of the child to help the child to communicate especially in the learning of English vocabulary. According to Hidayati (2007: 7) stated that vocabulary is the words that are taught in the foreign language. It mean, vocabulary 
is the word in a foreign language and vocabulary is the word that must be understand to communicate.

Morales (2004) defines vocabulary is a listing of the words used in some enterprise. Furthermore, Hidayati (2007: 7) stated that vocabulary is the words that are taught in the foreign language. It is concluded vocabulary is the word in a foreign language and vocabulary is the word that must be understand to communicate.For the improving students interest in english vocabulary, the researcher use picture as media in learning process.

According to Daryanto (2010), media is effective media to carry out well-planned teaching processes. Moreover, according to Azhar (2011), media is a tool for learning process both inside and outside the classroom, further explained that the learning media is a component of learning resources or physical vehicles that contain intruksional material in the students environment that can stimulate students to learn. It the above statement, it is concluded that media is effective tool the used teacher to in the learning process. According to Heinich in Widyastuti and Nurhidayati (2010) there are some types of instructional media that can be used by teacher that is : 1) Print / text media. 2) Exhibition / display media. 3) Audio media. 4) Pictures. 5) Multimedia. 6) Internet-based media. In this study, the researcher use picture as media.

Picture is a tool in the learning process in conveying various messages from the subject matter that will be conveyed by the teacher to the students (Djamarah, $2006: 122$ ). Furthermore, according to Onodera (2008), picture is replicas of nature. Some have encountered pictures that are exactly like an area or imitate a place in this part of the worrld. For example : picture of mountains, lakes, river etc. It can be concluded that picture is tool in the learning media in the form of picture that are exactly the nature. Furthermore, Wright (1989 cited in Apsari, 2017) proposes that there are some roles that pictures can have in the teaching of writing. Firstly, pictures can motivate students and make them want to pay attention and take a part. Secondly, pictures contribute to the context in which language is used. Thirdly, pictures can be described in an objective way or responded to subjectively. Fourthly, pictures can cue responses to questions. Finally, pictures can stimulate and proviide information to be referred to in conversation, discussion and storytelling.

Based of the above statement, the researchers use picture media as an effective media at TK Nur Assalam.

\section{METHOD}

In this study the researchers use CAR (Classroom Action Research). According to Creswell (2008: 597) CAR is a systematic process used by teacher (or other individuals in the educational context) to captue quantitative and qualitative data in order to improve educational components, such as teacher teaching techniques or student learning processes. Furthermore, according to Gwyn (2002) Action research is research methods by educators to find out what is best for learning in a classroom so that the classroom learning provides the best result. Based on the statement, CAR is activities teacher teaching technique or student in learning process.

The participants of this research were 6 students of TK Nur Assalam they are Rais, Erin, Zilva, Neta, Agil and Nura. Although their learning focus is only 5-7 minutes but, they fun and spirit in the learning process.

In this study, the researchers use Kemmis and Mc Taggart approach that is two cycle. Cycle I that is : 1) Planning I. 2) Implementation I + Monitoring I. 3) Reflection I. Cycle II that is : 1) Planning II. 2) Implementation II + Monitoring II. 3) Reflection II. To analyze data, the researcher observation that is during the study and after the study. 


\section{RESULTS AND DISCUSSION}

Before giving treatment, students not enthusiastic in learning process. Students difficult while in learning English. To improve students interest in English vocabulary, the researcher use picture media as a one kind of visual media, the use picture media the students enthusiastic and fun learning in learning process while use picture media.

From the result of research indicate that when pre-action take result (15\%). In cycle I, it increased to $(55 \%)$ sufficient criteria. In cycle II, it increased again to $(85 \%)$ good criteria. So, the increase that occurred from the pre-action to the first cycle that is $(40 \%)$. The increase from cycle I to cycle II that is (30\%). And increase from pre-action to cycle II that is (70\%). From the research results obtained, then to increase interest in student learning in English vocabulary can be improved by using the media picture in the learning process.

It is concluded that picture media effective to improve students interest in vocabulary English.

\section{Diagram 1}

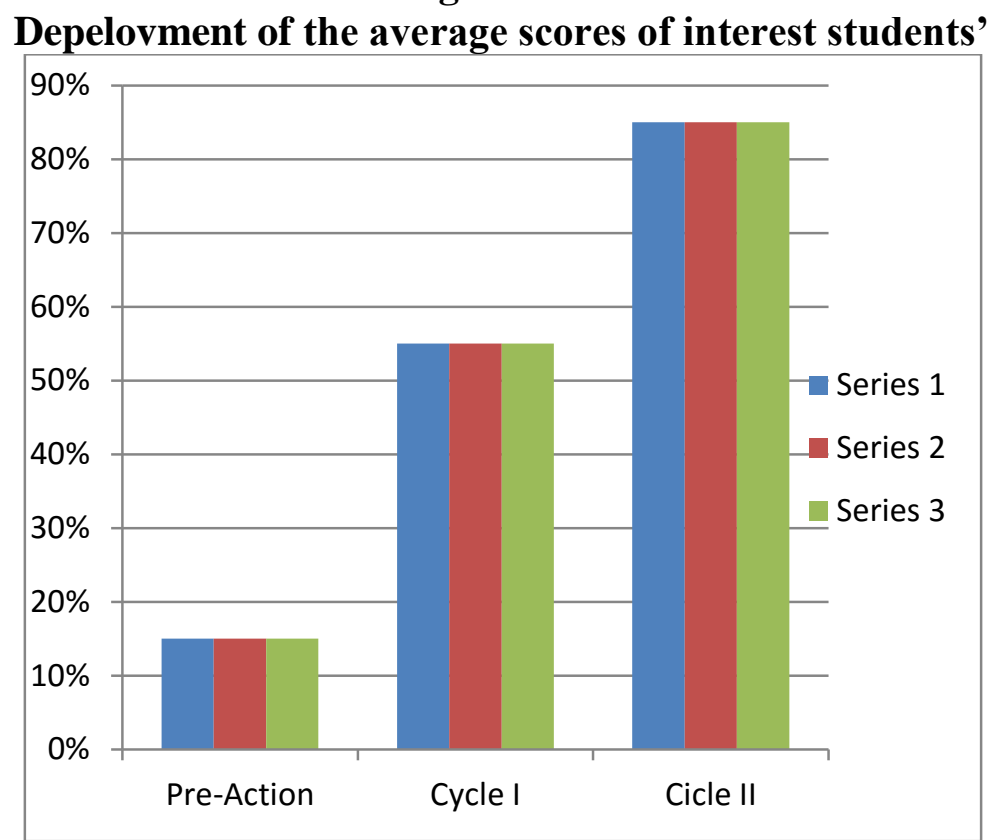

From that diagram, it can be seen that the average value of interest students, started from preaction, cycle I, cycle II increase. So, the improving students interest in English vocabulary can improve their vocabulary looks good.

\section{CONCLUSION}

Based on the research question in chapter first, it can be concluded that The picture media can improve students vocabullary at TK Nur Assalam. The research given some suggestions:

1. The teachers can use picture media in learning activities

2. The teachers and parents should impove motivation to learn better.

3. The teacher must create a variety of learning media to attract students learning interest.

4. For the researcher can be used as input for further research

\section{ACKNOWLEDGMENTS}


We thank the family, parents, friends and lecturers who have given us support both morally and materially, so that we can complete and publish our article.

\section{REFERENCES}

Apsari, Y. (2017). the Use of Picture Series in Teaching Writing Recount Text. ELTIN JOURNAL, Journal of English Language Teaching in Indonesia, 5(2), 51. https://doi.org/10.22460/eltin.v5i2.p51-56

Azhar. (2011). Media Pembelajaran. Jakarta : PT. Raja Gdafindo Persada

Bimo, Walgito. (2010). Pengantar Psikologi Umum. Yogyakarta : Andi Offset

Cresswell. (2008). Educational Research : Planning, Conducting and Evaluating Quantitative and Qualitative Research. Boston : Pearson Education, Inc.

Depdiknas. (2005). Undang-Undang RI No. 20 tahun 2003 tentang Sistem Pendidikan Nasional Pasal 1, Butir 14.

Daryanto. ( 2010 ). Media Pembelajaran. Yogyakarta: Grava Media.

Djamarah \& Zain. (2006) . Strategi Belajar Mengajar. Jakarta : Rineka Cipta.

Gwyn. (2002). Metode Pembelajara. Jakarta : Modul

Hidayati, Suci. (2007). The Analysis of Students Ability in Using Derivation Vocabullary. Bengkulu

Mansur. (2005). Pendidikan Usia Dini Dalam Islam. Yogyakarta : Pustaka Pelajar

Tamiya Onodera. (2008). Digital Image Processing.

Widyastuti, H. Sri dan Nurhidayati. (2010). Pengembangan Media Pembelajaran Bahasa Jawa. Skripsi. Universitas Negri Yogyakarta. 